\title{
THE BAGRY RESERVOIR - PART 3. THE APPLICATION OF HYDRO-DRONE SMART-SONAR-BOAT IN BATHYMETRIC MEASUREMENTS OF INACCESSIBLE WATER AREAS
}

AGH University of Science and Technology in Krakow

Faculty of Mining Surveying and Environmental Engineering

Keywords: Bagry Reservoir, hydrographical measurements, application of hydro-drones

\begin{abstract}
Within the borders of the city of Cracow there are several water bodies that are important and valuable in ecological, aesthetic (landscape), economic and recreational aspect. One of them is the Bagry Reservoir, called Bagry Wielkie, situated in Płaszów, in the neighbourhood of the zone designed for industry, warehouses, transport (railway no. 91) and residential areas. Over the whole period of its existence and use, the water body was subdued to frequent geometric changes. Transformations resulted mainly from the demand of the neighbouring brickyards for clay, gravel and sand exploited for the needs of the development in the area of Płaszów, especially during Nazi occupation and the stage of the first phase of the industrialization of socialist Poland (1950-1970). The end of exploitation in 1972 and leaving the excavation without carrying out the process of remediation measures caused the return of ground waters to the state of hydro-geological (spontaneous liquidation of the depression funnel). The change in the level of the water table and a very complicated shoreline, typical in this type of post-exploitation water bodies, often cause the separation of the peripheral fragments of the water body from its main part. This limits the possibility of applying popular bathymetric sets, i.e. echo-sonars fixed on manned boats, carrying out the process of acoustic probing in water areas. In 1999, the small water body located in the south-west part of the study area, was still an integral part of the Bagry. Nowadays it is separated from the main body with a narrow piece of land. Thus the supplementation of hydrographical documentation required the application of automatic measurement tools. The article presents the results of the application of hydro-drone Smart-Sonar-Boat in making a bathymetric map of this poorly accessible fragment of Bagry, making contribution to the cartographic documentation made by R. Gawałkiewicz (Gawałkiewicz R., 2017).
\end{abstract}

\section{ZALEW BAGRY - CZĘŚĆ 3. ZASTOSOWANIE HYDRODRONA SMART-SONAR-BOAT W POMIARACH BATYMETRYCZNYCH TRUDNODOSTĘPNEGO OBSZARU WODNEGO}

Słowa kluczowe: Zalew Bagry, pomiary hydrograficzne, zastosowanie hydrodronów

\section{Streszczenie}

W granicach miasta Krakowa zlokalizowanych jest kilka ważnych i wartościowych pod względem przyrodniczo-krajobrazowym, gospodarczym oraz rekreacyjnym akwenów wodnych. Jednym z nich jest Zalew Bagry zwany Bagrami Wielkimi, położony w Płaszowie, w sąsiedztwie strefy przemysłowej, magazynowej, komunikacyjnej (linii kolejowej nr 91) oraz mieszkalnej. W całym okresie jego istnienia i użytkowania, akwen ulegał częstym zmianom geometrycznym. Przeobrażenia wynikały głów- 
nie z zapotrzebowania okolicznych cegielni na glinę oraz żwirów i piasków eksploatowanych na potrzeby prowadzonych inwestycji w rejonie Płaszowa, zwłaszcza w okresie okupacji hitlerowskiej oraz etapu pierwszej fazy industrializacji socjalistycznej Polski przypadającej na lata 1950-1970. Zakończenie eksploatacji w 1972 roku i pozostawienie wyrobiska bez przeprowadzenia procesu rekultywacji, spowodowało powrót wód gruntowych do stanu równowagi hydrogeologicznej (samoistna likwidacja leja depresji). Zmiana poziomu zwierciadła wody oraz bardzo urozmaicona linia brzegowa, charakterystyczna dla tego typu wyrobisk pogórniczych, powoduje często separację peryferyjnych fragmentów wyrobiska od części głównej akwenu. To z kolei ogranicza możliwości zastosowania popularnych zestawów batymetrycznych, tj. echosond montowanych na pokładach łodzi lub innych jednostek pływających w procesie sondowania akustycznego takich stref wodnych. Zlokalizowane w części południowo-zachodniej oczko wodne, które jeszcze w 1999 roku stanowiło integralną część Zalewu Bagry, dziś oddzielone jest od części głównej akwenu wąskim pasem terenu. Stąd uzupełnienie dokumentacji hydrograficznej wymagało zastosowania automatycznych narzędzi pomiarowych. W artykule przedstawiono wyniki zastosowania hydrodrona Smart-Sonar-Boat w opracowaniu mapy batymetrycznej trudnodostępnego fragmentu Bagrów, co stanowi uzupełnienie opracowania kartograficznego części głównej sporządzonego przez R. Gawałkiewicza (Gawałkiewicz R., 2017).

\section{INTRODUCTION}

The development of remote sensing technologies and geographic information systems allows precise recording of detail data referring to the elements of natural environment and its changes in time. Available technologies in surveying and photogrammetry allow not only precise documentation of available objects on the surface, but also documentation of underground objects (underground mine infrastructure) or objects submerged under water (lakes, reservoirs, rivers etc.). Integration of geo-spatial data obtained by different measurement methods provides precise sets, extremely useful in the process of the analysis and interpretation of phenomena and the control and protection of selected elements of natural environment at the application of geo-information and statistic tools.

Geodetic services include documenting waters of all types - flowing and standing waters. In case of the available objects, the inventory of the bottom of a river or lake is carried out from a manned boat equipped with a sonar and GPS receiver. In the situation of limited access to the shoreline (steep scarps, landslide threat of scarps in the shore area, presence of litoral vegetation and the condition of its protection) or economic factors (small area of the water body), it seems justified to use equipment for automatic recording of spatial geodata. According to Kudas D. \& Czempas T., (2016), vast majority of inland water bodies in Poland (including borrow pits), have outdated bathymetric maps or have no maps at all. The knowledge of morphometric characteristic of the water body is necessary in making detail limnological, hydrological and hydrobiological characteristics, especially in case of making plans of water area management and the protection of natural resources.

The Bagry Reservoir called Bagry Wielkie, makes one of the largest post-exploitation water bodies located at the borders of the Cracow City (total area is 30.27 ha). It is also a typical urban water body of the area below 100 ha, reactivated in the period of second phase of industrialization of Poland in a socialist/communist style.

The water body consists of two landlocked water areas, where the main body fulfils recreational and sports, as well as economic functions (fishing). Semi-automatic measurements of the main water body were carried out from a manned boat and the results were published (Gawałkiewicz R., 2017). The second, much smaller water body is left in a natural state and its function is providing habitats for many species of flora and fauna (including the area of meadows). It is located in the south-western part of the reservoir and isolated from the managed part with a dike. It makes a landlocked, difficult-to-access water body of small retention (total volume of the waters $\mathrm{V}<5$ million $\mathrm{m}^{3}-$ Bieroński J., 2005). It is permanently filled with water and the values of retention changes (fluctuation of the water table level) are small, which proves that the balance of inflowing waters (precipitation on the surface of the reservoir, inflow of surface waters and ground waters) and outflow (evaporation, ground outflow) is positive. The shoreline and littoral zone is overgrown by reed (Phragmites australis) and reed mace (Typha latifolia), limiting the access to the waters of the reservoir and preventing from the application of manned boats equipped with measurement instruments. Thus surveying tasks require the adjustment of technologies to the existing field conditions. Paraphrasing the words of 
engineer Marjan Hełm-Pirgo (Hełm-Pirgo M., 1928), it can be said that surveying technology is changing, however field conditions remain the same and we have to adjust to them.

The article presents the results of the hydrographic inventory with the application of hydro-drone SmartSonar-Boat (construction by D. Madusiok) in the smaller part of the Bagry Reservoir - landlocked water area designated in the Local Land Management Plan (Miejscowy Plan Zagospodarowania Przestrzennego MPZP), as an element of the area of the ecological site (Kudłek J., et al. 2005). Data contained in this article make contribution for the hydrographic information contained in (Gawałkiewicz R., 2017).

\section{THE ORIGIN AND THE FORMATION OF THE BAGRY RESERVOIR IN THE SOUTH-WESTERN PART}

The analysed water area owned by the municipality of Cracow (the area of inland surface waters - marked in figure 1), makes a relic of mining activities carried out already after the 2nd World War. It is localized within the borders of the Quarter (Dzielnica) XIII - Podgórze, in the structural unit of Płaszów and urbanistic unit no. 30 „Myśliwska - Bagry”. Additionally, according to the landscape and ecological division, it is situated within the borders of Igołomia-Brzesko Meadow-andField Area (Kudłek J., et al. 2005)

The analysed region of the studies was industrialized already in 19th century. It was a material supply base for the city of Cracow. A particular role was played by brickyard industry. It was because of huge resources of Podgórze, i.e. deposits of clay and sand (Zabłocie, Płaszów) and limestone (Krzemionki), which are basic materials for the production of bricks and tiles. Austrian plans of fortifying the city in $1850-1914$ in the framework of the constructed Stronghold of Cracow, assumed the building of 100 objects of military significance. Brick was then the main construction material used by Austrian engineers. During 1st World War, in the analysed part of the mining area (south-west area), Russian prisoners of war worked in the mining of clay and sand. One can assume that in 1914-1916 sand was exploited for the needs of a huge Austrian railway transportation project - large marshalling yard in Prokocim, which was then modernized and developed during Nazi occupation.

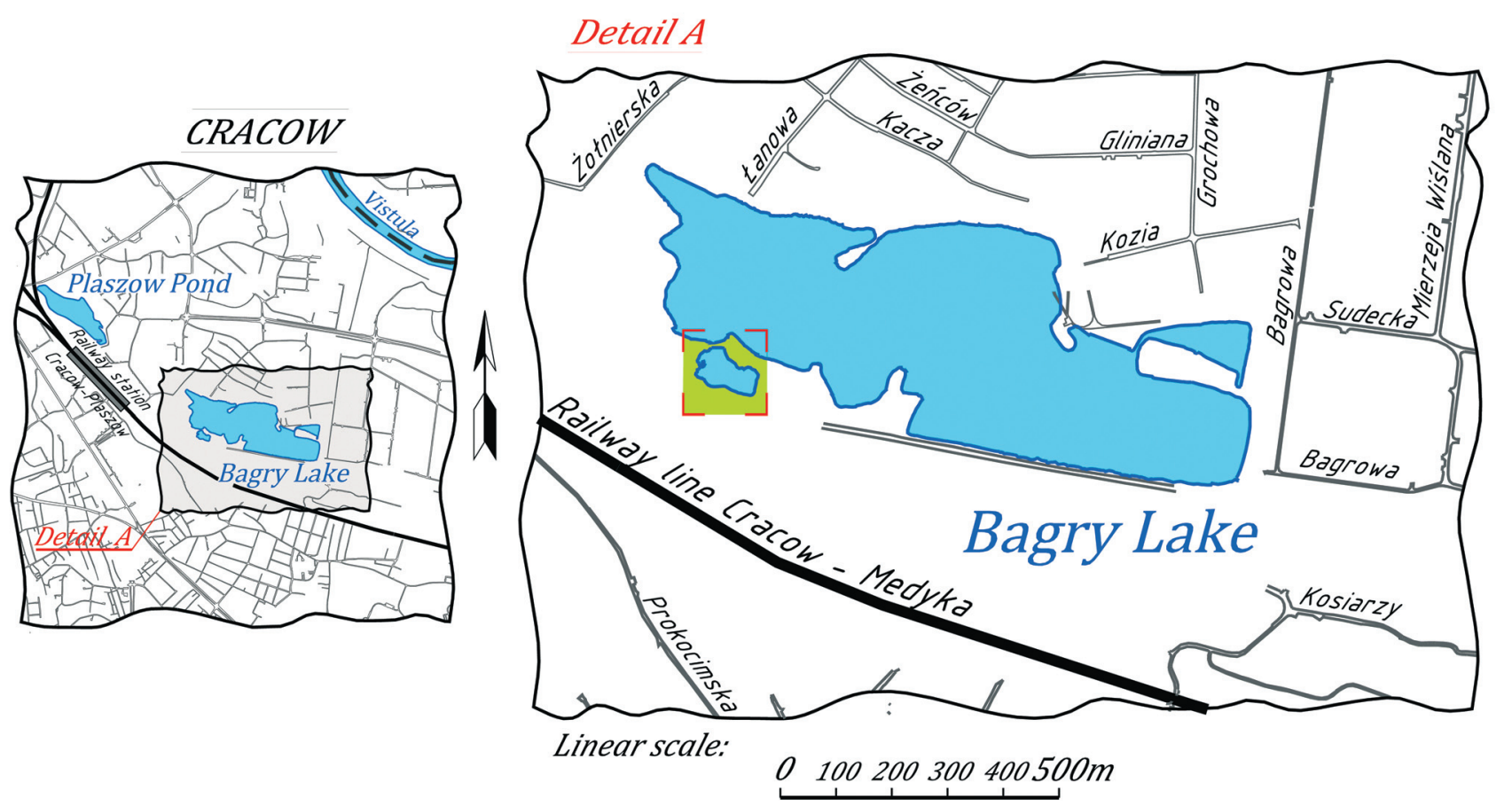

Fig. 1. Localization of the inventoried object on the background of the fragment of the map of Cracow Rys. 1. Lokalizacja inwentaryzowanego obiektu na tle fragmentu mapy Krakowa 


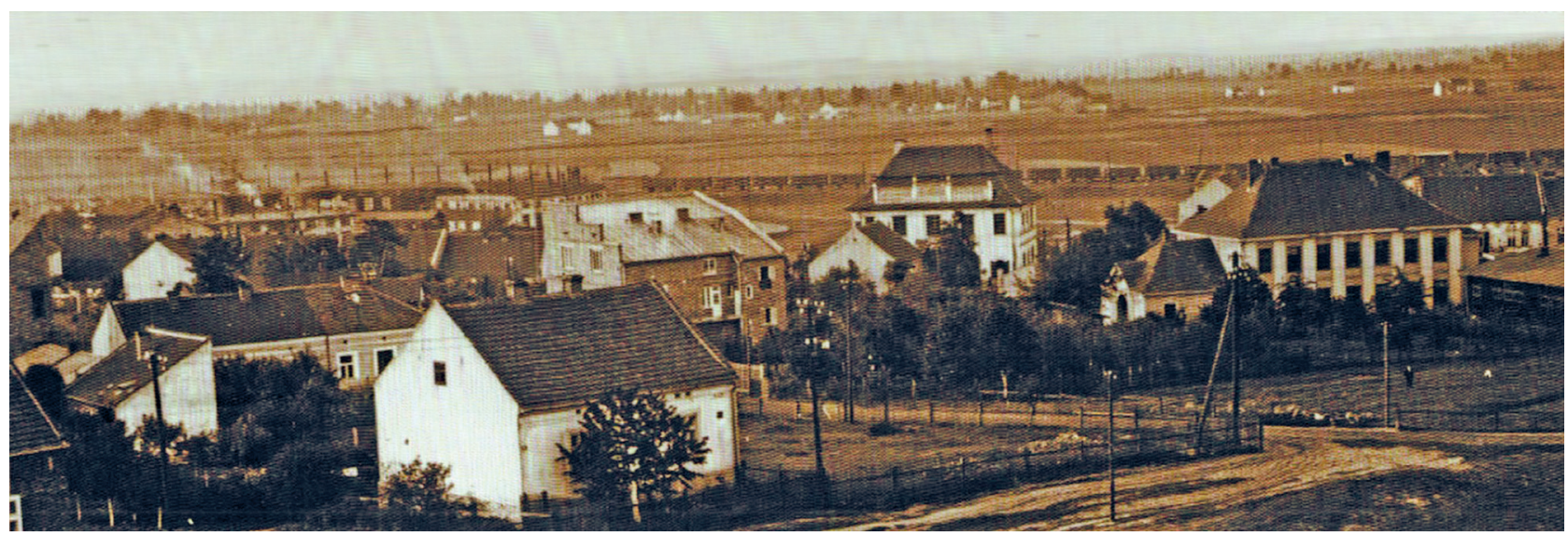

Fig. 2. The view on the railway settlement „Szutry” and meadow areas of Prokocim and Płaszow - 1930s. (Source: Organization Committee of the celebration of 650th anniversary of Prokocim - calendar 2018.)

Rys. 2. Widok na kolonię kolejarską „Szutry” oraz obszary łąkowe Prokocimia i Płaszowa - lata 30. XX wieku (Źródło: Komitet organizacyjny obchodów 650-lecia Prokocimia - kalendarz 2018.)
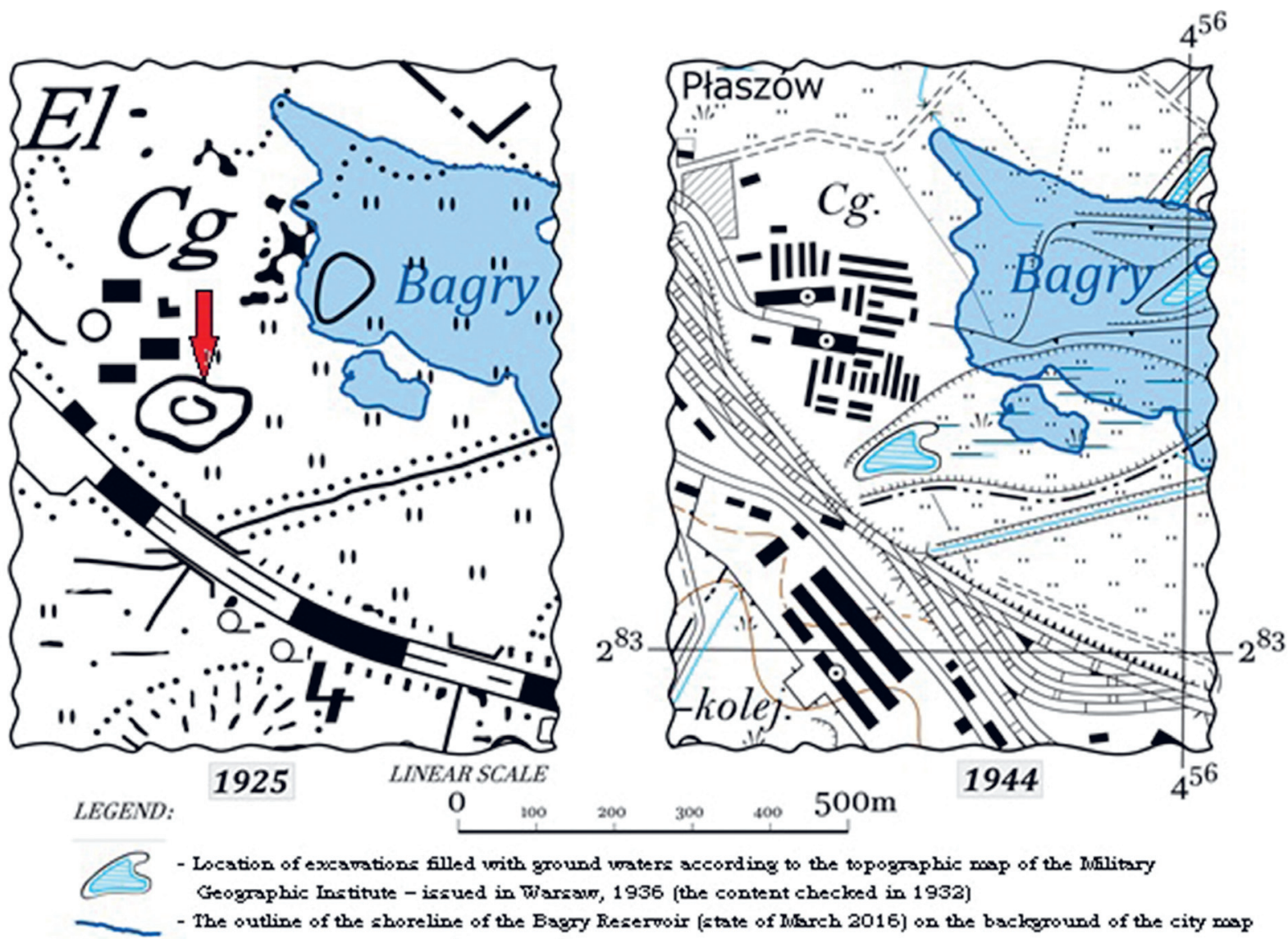

- Location of excaratione fllled with ground waters according to the topographic nop of the liblitary Geographic Institute - iszued in Wharsav, 1936 (the content checked in 1932)

- The outline of the shoreline of the Bagry Fezerwoir (ztate of Mbreh 2016) on the bacleground of the eity map

Fig. 3. Localization of the inventory outline of the water area on the background of archival maps of 1925 and 1944 (vectorization: R. Gawałkiewicz)

Rys. 3. Lokalizacja zarysu inwentaryzowanego obszaru wodnego na tle map archiwalnych z 1925 i 1944 roku (wektoryzacja: R. Gawałkiewicz) 
In the cartographic document of 1925 (section 3964), being the reproduction of the map made by the Military Geographic Institute (Wojskowy Instytut GeograficznyWIG) in scale 1:75 000 of 1914, there is graphical information on the localization of the first mining excavation (figure 3a). The confirmation of the existence of a small mining excavation could be found in another map of 1925 in scale 1:100 000 made by WIG (section A48 B30 Krakow), also based on data of 1914, which illustrates the presence of industry, i.e. small Płaszów Factory of Bricks and Tiles (Płaszowska Fabryka Cegieł i Dachówki S.A - „Płaszowianka” - (brickyards are marked with abbreviation Z.O.), situated in the neighbourhood of the future excavation. The map documents the state of the surface of the terrain of meadows (figure $3 \mathrm{~b}$ ), on which in the neighbourhood of railway line Krakow - Medyka (former Galician Railway of Archduke Charles Louis), first in this area excavation was marked (as „„” in figure 3 a). In an archive photo of 1930 s, showing the railway settlement "Szutry" located in the region of Old Prokocim and Płaszów in the background (figure 2), one can see just over the fan railway depot regular water areas being the trace of exploitation. Just over the Galician Railway of

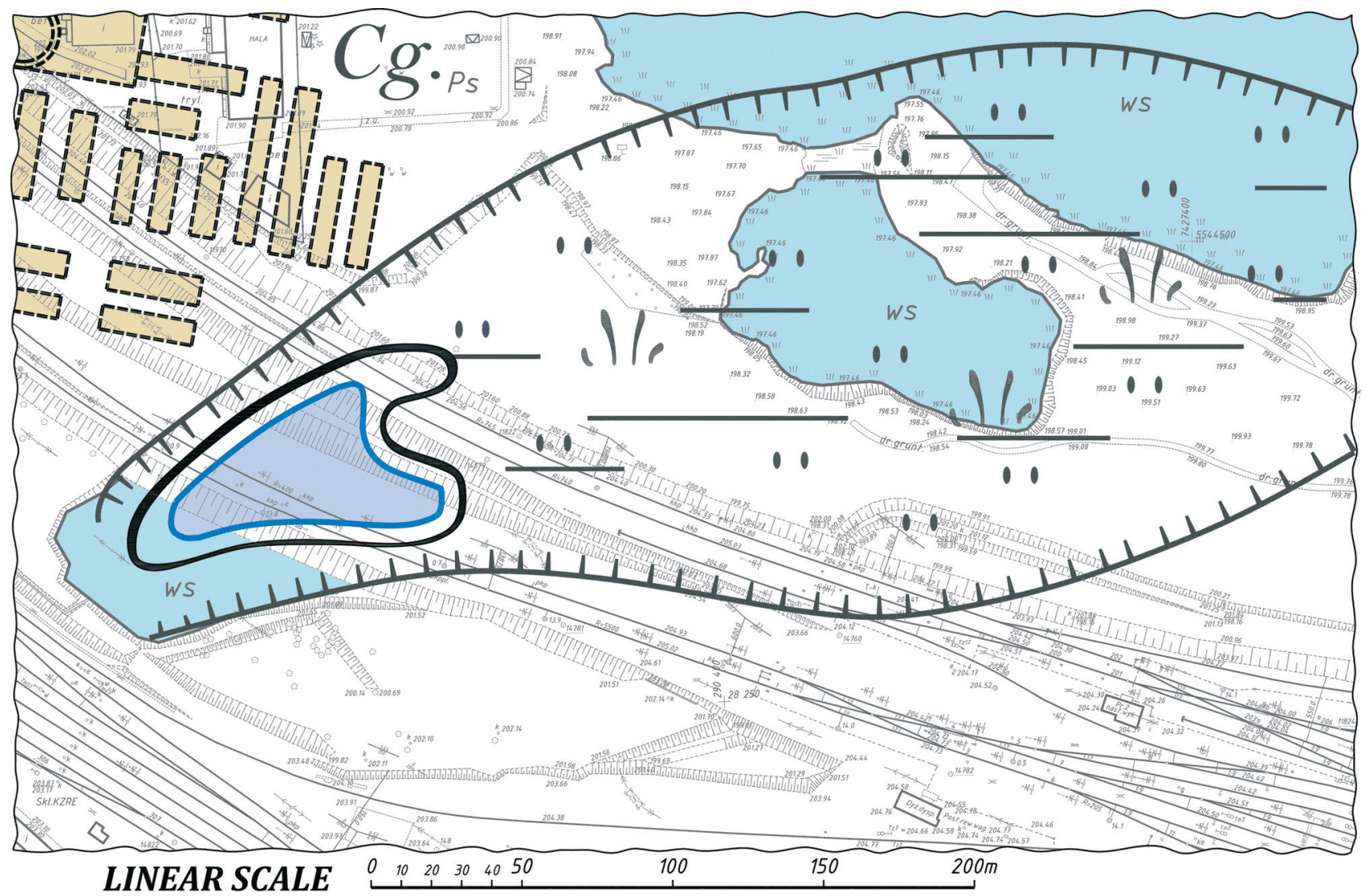

\section{LEGEND:}

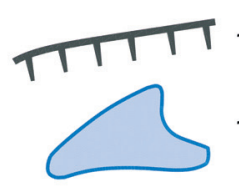
- przybliżony zarys skarp nadkładowych
wyrobiska górniczego

- zarys wyrobiska wypetnionego wodq

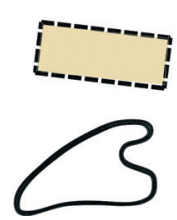

- przybliżony zarys nieistniejących obiektów przemysłowych Płaszowskiej Fabryki Cegieł i Dachówki S.A.

Fig. 4. Localization of first mining excavations of 1936-1944 in the study area on the background of the main map - vectorization R. Gawałkiewicz (sections 1224: A-4, C-2, C-4, D-1).

Rys. 4. Lokalizacja pierwszych wyrobisk górniczych z 1936-1944 w rejonie analizowanego obszaru na tle mapy zasadniczejwektoryzacja R.Gawałkiewicz (sekcje 1224: A-4, C-2, C-4, D-1). 


\section{LINEAR SCALE}

$\mathrm{O}_{10203040} \mathbf{5 0}_{60} 70 \quad 8090 \mathbf{1 0 0 m}$

\section{PROFILE A-A}

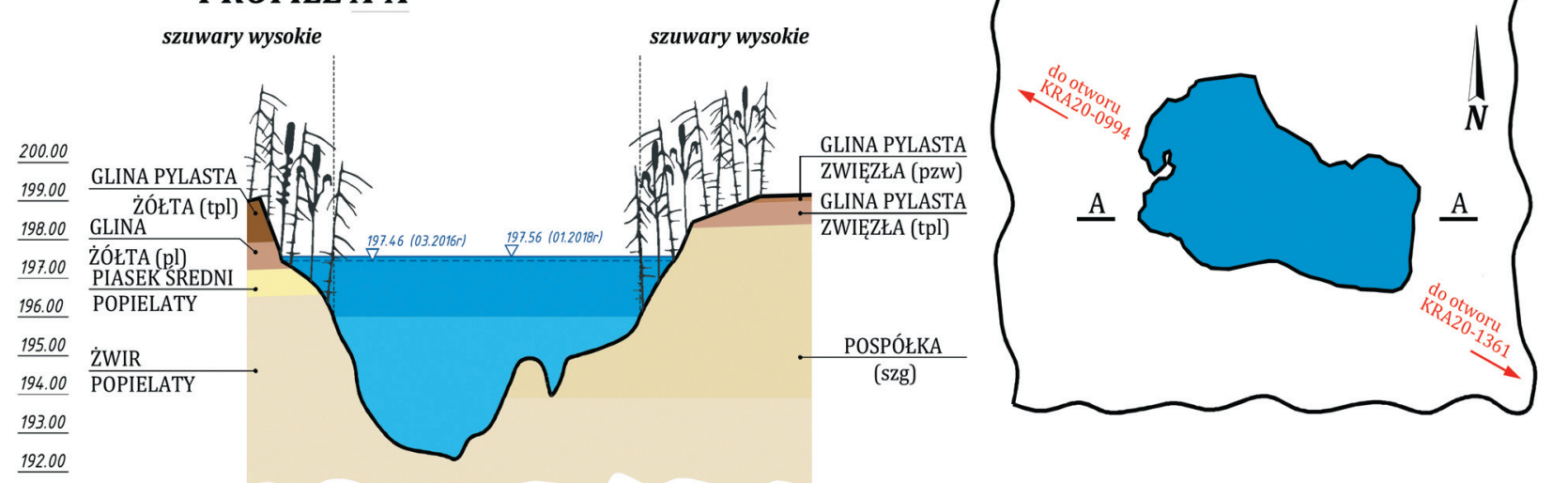

Fig. 5. Geological cross-section through the difficult-to-access part of the Bagry Reservoir based on the data from geologicalengineering boreholes. (Source: www.bazagis.pgi.gov.pl) and bathymetric measurement.)

Rys. 5. Przekrój geologiczny przez trudnodostępną część Zalewu Bagry opracowany na podstawie danych otworów geologiczno-inżynierskich. (Źródło: www.bazagis.pgi.gov.pl) oraz pomiaru batymetrycznego.)

Archduke Charles Louis there is a view of the meadow area, which is now covered by the Bagry Reservoir; we can also see residential and industrial buildings of Płaszow.

In the inter-war period brick industry was still important, which is confirmed by the information contained in the preserved detail topographic maps of Podgórze, including:

- Polish General Staff - Geographical Section marked as: Town Plans of Poland No. 4435 Kraków (first edition) - scale 1:25000 (a fragment of the map - figure 3a);

- Deutsche Heereskarte 48/30G Krakau - Generalgouvernement, scale 1:25000, based on the data of the Military Geographic Institute of 1934 (figure 3b),

where dominating elements are factories of ceramic construction materials (brickyard marked as $\mathrm{Cg}$ ) in the area of Zabłocie and Płaszow.

During the Nazi occupation the industrialization of this part of Podgórze continued and further plants and factories were built for the needs of 3rd Reich (Salwiński J., 2011). Especially the map of 1944 illustrates the already developed infrastructure of brickyards and the excavation (to the border with Prokocim), which during the modernization of the by the railway junction in Płaszow and Prokocim by the Nazis in 1942 - 1945 to facilitate military transport requiring the development of the railway spur system and depot in Prokocim were partially liquidated - figure 4 (Gawałkiewicz R., 2017a). The development of railway systems on embankments in the neighbourhood of Bagry paradoxically formed a natural barrier separating the water body with the adjacent area of natural greenery from the busy part of the city (Mytych D., 2016)

The analysis of archival section of the main map, scale 1:500, made in 1984 by the Cracow Surveying Enterprise (Krakowskie Przedsiębiorstwo Geodezyjne) in Cracow (sections: A-4, C-2, C-4, D-1 in the system of plane coordinates of the city of Cracow), confirms the range of mining illustrated in the German document of 1944 based on WIG data of 1936. The transformation of maps to system 2000/21 allows the correlation of cartographic data, which confirmed the range of exploitation carried out until the outbreak of 2 nd World War (figure 4). The ordinates the area were preserved in the maps of 1980s (source: GODGiK in Krakow) within the outline of the overburden scarp and obtain in 2016 (measurement: R. Gawałkiewicz) and the analysis of archival profiles of geological and engineering boreholes (figure 5): KRA20-0994 and KRA20-1361 localized in 


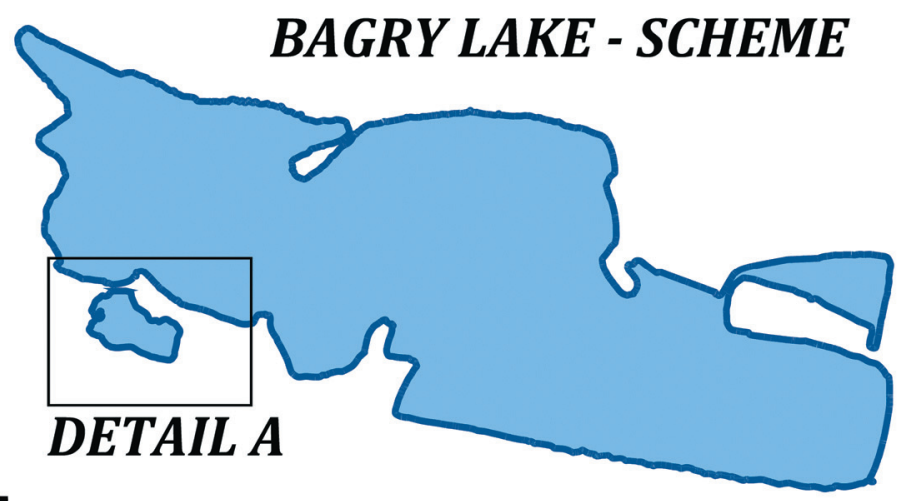

DETAIL A

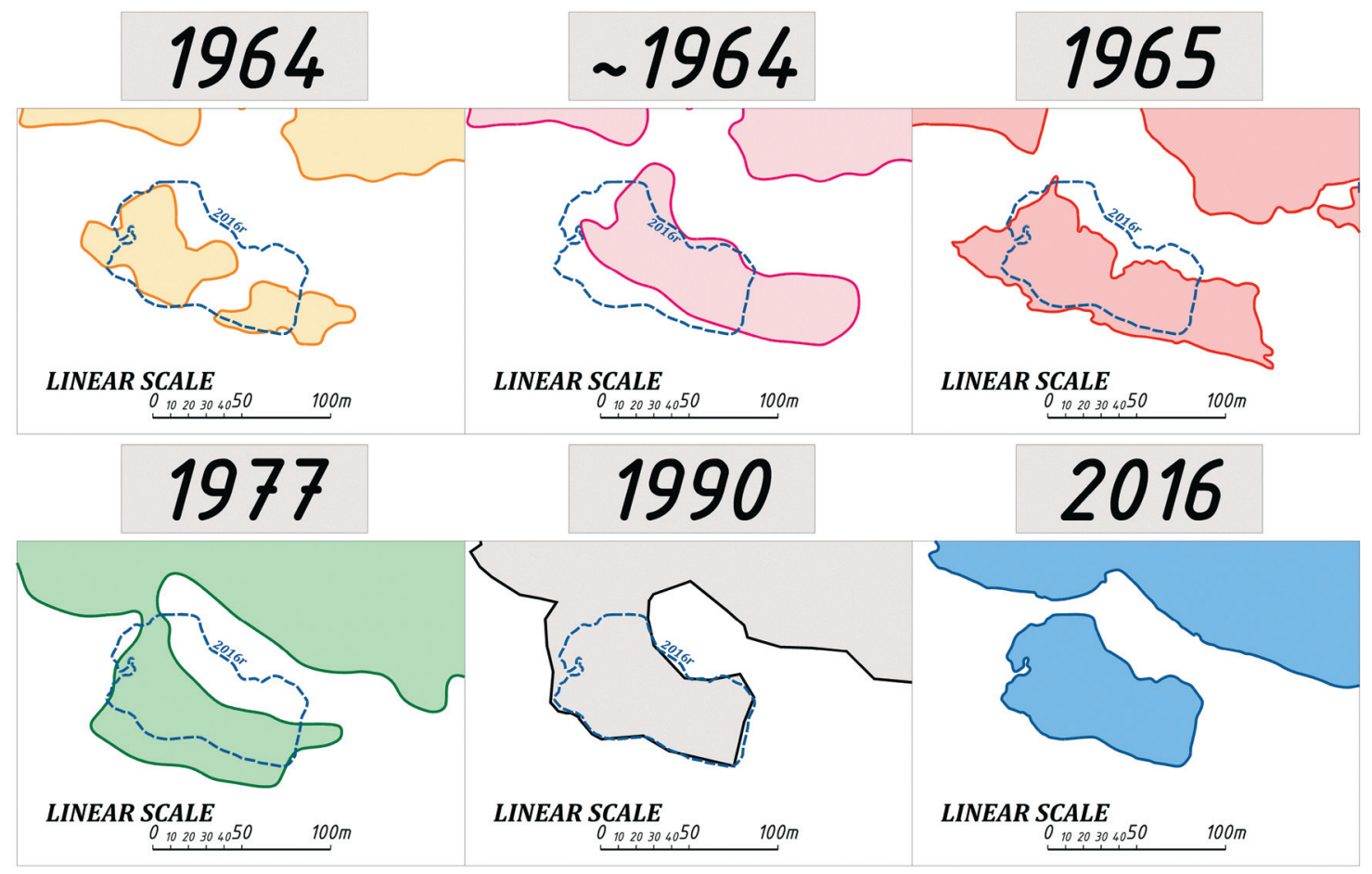

Fig. 6. The scheme of changes in the difficult-to-access part of the Bagry Reservoir in 1964-2016.

Rys. 6. Schemat zmian trudnodostępnej części Zalewu Bagry w okresie 1964-2016.

the neighbourhood of the analysed study area (source: www.bazagis.pgi.gov.pl), allows detail specification of the direction of exploitation of clay and sand in the south-western part of Bagry.

After the first stage of the reconstruction in 1945-1950 , there was the first phase of industrialization of socialist Poland in 1950-1970. The reactivation of mining activities in the western and south-western part took place in the second decade, when the authorities decided that the key industry would be the one connected with the raw materials. In this period one should look at the begin- ning of mining in the examined water body, which can be confirmed by the cartographic document based on the airborne photo of 1964 (figure 4). Undertaking mining activities resulted from unused so far resources of sand, gravel and aggregates (figure 5), as basic material for the production of concrete. The dynamics of the exploitation process in this part of the mining area in 1964-1965 is confirmed by subsequent phases of the geometry of excavation based on airborne photos and archival maps (source: www.planowanie.um.krakow.pl/bppzoom - access December 2017), presented in figure 6. 
In this period there was the highest dynamics of the development of the cities of Southern Poland. It resulted from the migration of people to big cities, due to the growth of their industrialization, and consequently, the development of industrial infrastructure and blocks of flats built of precast concrete slab as residential buildings for future workers. The construction industry was based on local resources (Szymańska D., 2002). Unfortunately, demographic dynamics of the cities was halted by the economic crisis in 1970s. With the economic crisis there was a demographic stagnation of large city centres, as well as the decline of numerous mining enterprises exploiting deposits of aggregates and clay located within the borders of many city agglomerations. Thus in 1972 the decision was made to end exploitation in the present area of Bagry Wielkie.

\section{DESCRIPTION OF MEASUREMENT INSTRUMENTS}

Bathymetric measurement of difficult-to-access water area in the south-western part of Bagry Wielkie, was carried out with the application of remote-control hydro-drone Smart-Sonar-Boat (Madusiok D., 2016). The boat (figure 7), was equipped with ultra-sonic sonar Lowrence Mark-4 (water-proof IPX7), working on two measurement frequencies: $83 \mathrm{kHz}$ (conic angle of the beam - 120o) or $200 \mathrm{kHz}$ (conic angle - 60o) in the range of depth $0 \div 305 \mathrm{~m}$ (source: www.echosonda.pl/ product info.php?product id=1535 - access February 2018). There was an option to install an HDI adapter of frequencies: $455 \mathrm{kHz}$ and $800 \mathrm{kHz}$ of conic angles 55o and $30 \mathrm{o}$, respectively. The adapter of transmitter's power $250 \mathrm{~W}$ RMS, empowered by $12 \mathrm{~V} / 75 \mathrm{~A}$, provided measurement frequency up to 10 records per second. The results of hydrographical measurements were recorded automatically (option: sonar $\log s$ ) on microSD or microSDHC in *.sl2 files). There was a possibility of live transmission of data to external devices using protocol NMEA 0183 Output and the history of the measurement could be seen (function: trackback) with the application of a coloured projector TFT LCD 4.3" of the recording module. Additionally, set Lowrence Mark-4 was equipped with GPS aerial to position the sonar in the absolute measurement (without the base station) by the application of the satellite augmentation system WAAS/ MSAS/EGNOS. The studies of actual accuracy of the positioning of sonar Lowrence Mark-4 in horizontal plane carried out by Madusiok D., (2018), allowed us to estimate the mean error of a single measurement on the level $\mathrm{mP}= \pm 1.05 \mathrm{~m}$ (in measurement mode Stop\&Go). In case of very complicated morphology of the bottom,

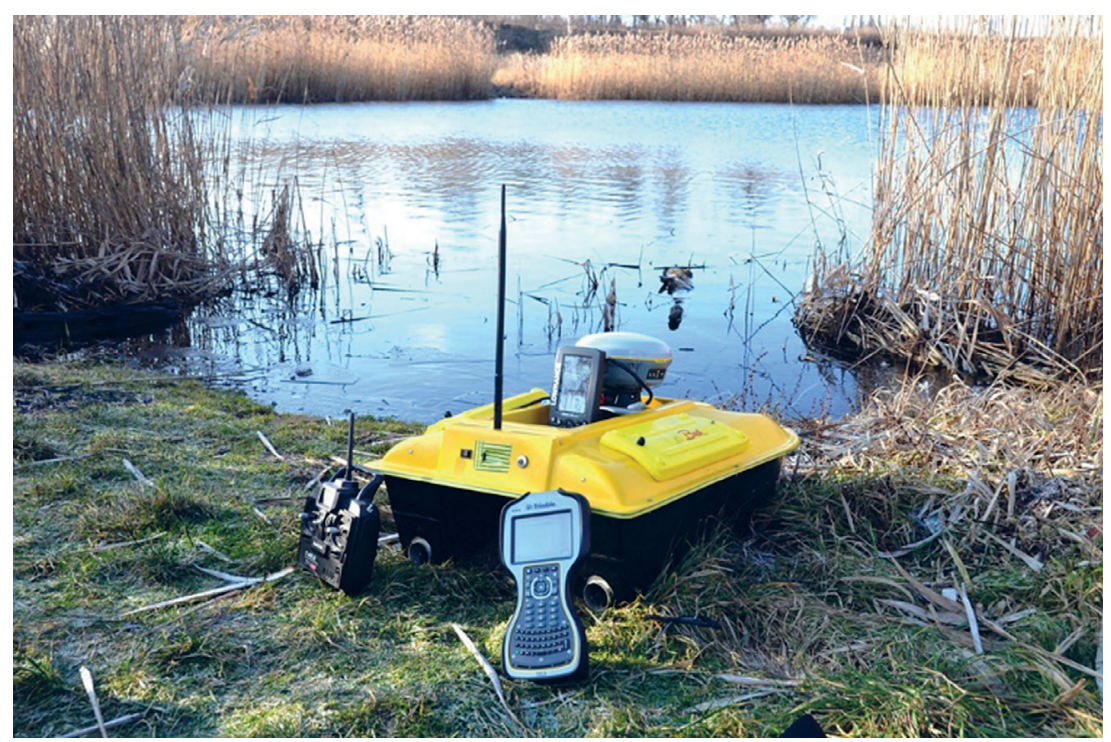

Fig. 7. The view of the measurement set: hydro-drone Smart-Sonar-Boat and GPS Trimble (aeriel R8s + controller TSC3) during bathymetric measurements of the difficult-to-access part of the Bagry Reservoir. (Photo: D. Madusiok.)

Rys. 7. Widok zestawu pomiarowego: hydrodron Smart-Sonar-Boat oraz GPS Trimble (antena R8s + kontroler TSC3) podczas pomiarów batymetrycznych trudnodostępnej części wodnej Zalewu Bagry. (Fot. D. Madusiok.) 

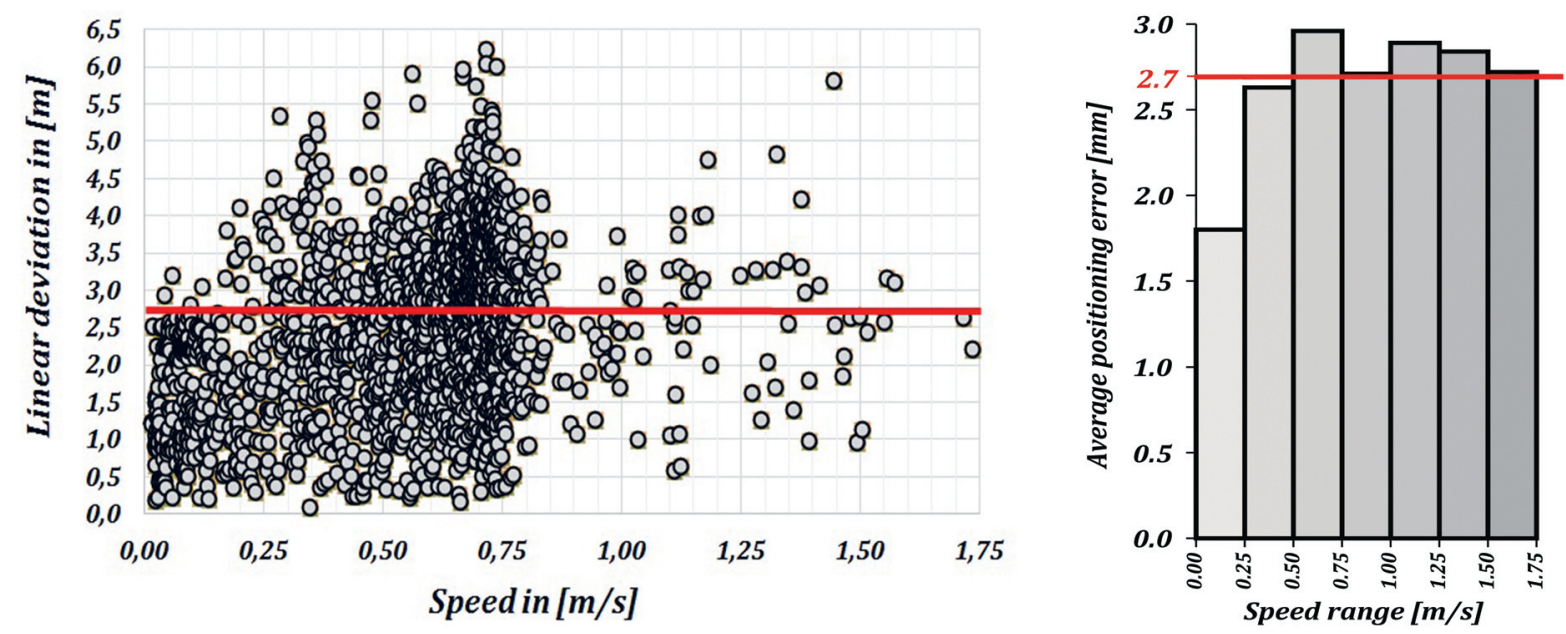

Fig. 8. The analysis of the distribution of linear errors of positioning, depending on the speed of the hydro-drone equipped with sonar Lowrence Mark-4 with GPS receivers.

Rys. 8. Analiza rozkładu błędów liniowych pozycjonowania w zależności od prędkości hydrodrona wyposażonego w sondę Lowrence Mark-4 z odbiornikiem GPS.

typical for old borrow pits, the error of positioning the points of bathymetric measurement, can significantly distort its real image. Thus, in the hydrographical measurement a classical GPS receiver R8s by Trimble was used. It was fixed aboard the hydro-drone (figure 7). The accuracy of accuracy determining the plane coordinates in a continuous mode was on the level $\pm 5 \div 10 \mathrm{~mm}$ (the report from GPS RTK/RTN measurement). To integrate plane coordinates XY marked by R8s (work in ASG-EUPOS system) with hydrographic information recorded by sonar Lowrence Mark-4 (work in EGNOS system), both devices were situated in the mode of continuous work of 1 second interval measurement. As a result of field work, 3387 pairs of points were marked. They made base for making the bathymetric map of the part of Bagry Reservoir that is difficult to access (density: 0.6 point $/ \mathrm{m} 2$ ). The combination of flat coordinates from both GPS receivers allowed the determination of the real accuracy of positioning bathymetric points during the work of the hydro-drone based on the theory of the error of real single measurement. This results in the mean error of individual measurement of positioning GPS receiver Lowrence Mark-4 was $\pm 2.7 \mathrm{~m}$ (figure 8), preserving the recorded track of parameters:

- total length of the track: $2.395 \mathrm{~km}$;

- the range of the speed of the hydro-drone $\mathrm{v}=0.01$ $\div 1.73 \mathrm{~m} / \mathrm{s}$;

- mean speed of the hydro-drone $\mathrm{v}_{\text {Mean }}=0.54 \mathrm{~m} / \mathrm{s}$.
The analysis of the relationship between the error of the sonar positioning and the boat speed showed that the smallest error of determining the position of the measurement system on the plane $( \pm 1.8 \mathrm{~m})$, is obtained when the speed of hydro-drone is small - up to $0.25 \mathrm{~m} / \mathrm{s}$ $(0.9 \mathrm{~km} / \mathrm{h})$ and the error grows significantly to $0.83 \div$ $1.16 \mathrm{~m}$ with the higher speed (figure

\section{THE RESULTS OF BATHYMETRIC MEASUREMENTS AND MORPHOMETRIC PARAMETERS OF DIFFICULT-TO-ACCESS PARTS OF THE RESERVOIR}

\subsection{Preliminary remarks}

The resources of natural and anthropogenic water bodies undergo constant changes. It results from the impact of many environmental factors, among others: amount and intensity of atmospheric precipitation, air temperature, the level of ground waters, hydrogeological properties of the ground, etc., as well as human activities in the neighbourhood water bodies (drainage of construction sites, building up the terrain limiting the possibility of the infiltration of precipitation water to the ground).

Because of that, in order to obtain reliable data for the whole area, in case of carrying out measurements of 
the water body components in different time, it is necessary to unify the reference level (ordinate of the water table). Due to the fact that the part used for recreation and sports (main part of the water body) was examined in March 2016 (Gawałkiewicz R., 2017), and the part being the ecological site (ecologically useful area) was examined in January 2018, the reference level for determination of morphometric parameters was taken as $21^{\text {st }}$ March 2016, i.e. $197.457 \mathrm{~m}$ a.s.l. Based on levelling measurements of the water table it was found that the level of the water table grew by $+0.103 \mathrm{~m}$ between March 2016 and January 2018.

\subsection{The analysis of the water body}

One of basic morphometric parameters, making the element of the control of water resources is estimating retention volume $\mathrm{V}$ of the water body. So far there is a range of methods calculating cubature of irregular objects (lake basins, slag heaps, mounds). The distribution of the points of hydrographical measurement illustrated in figure 9, allows the analysis of the changes in the size of the cubature of water resources, depending on the accepted calculation algorithm. The volume of the lake basin (to the level of the water table) was calculated with the following methods:

- summing the partial volume of the water basin;

- bathygraphical curve, presenting the graph of the function attributing the volume of water contained in a given range of depth - figure 10;

- numerical method - kriging, based on a regular GRID (program Surfer - Golden Software).

The numerical model of the bottom and litoral zone allows on-line updating of morphometric parameters. The list of basic morphometric indicators of the inventoried part (areas of ecological sites) was put in table 1. Applying the interpolation method based on GRID a bathymetric map of the examined difficult-to-access part was made, which was illustrated in figure 11.

Post-exploitation and their parts are characterized by a specific morphometry. The shape of the lake basin is a result of the layout of the bottom and the verges of an old exploitation field, which is usually modified at the stage of technical reclamation (before total flooding). The feature of such water bodies is their large mean depth referring to maximal depth. Large slope of the scarps and flat bottom of the concave form determine

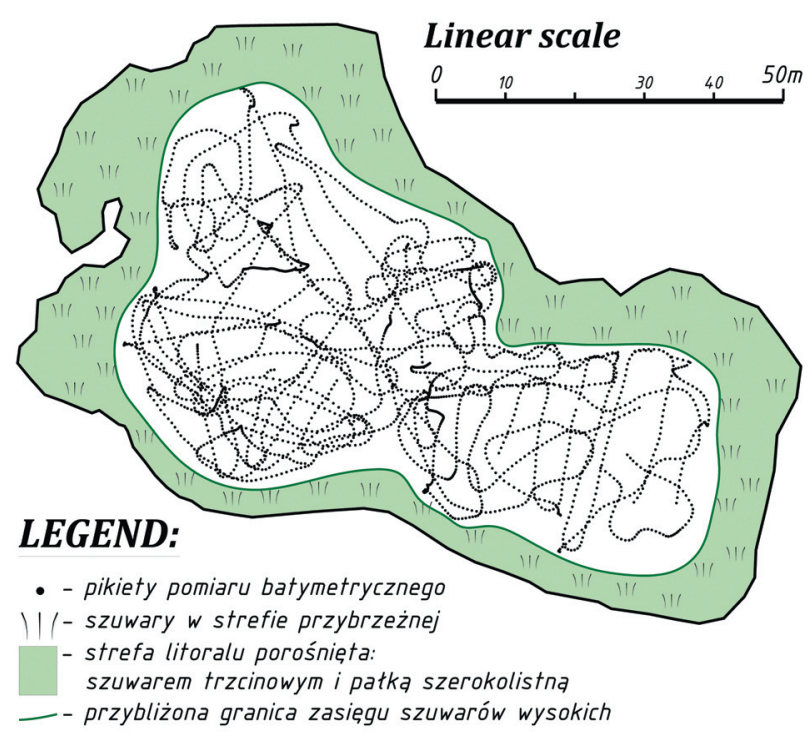

Fig. 9. Distribution of the points of hydrographic measurement of the difficult-to-access part of the Bagry Reservoir.

Rys. 9. Rozkład punktów pomiaru hydrograficznego trudnodostępnej części Zalewu Bagry.

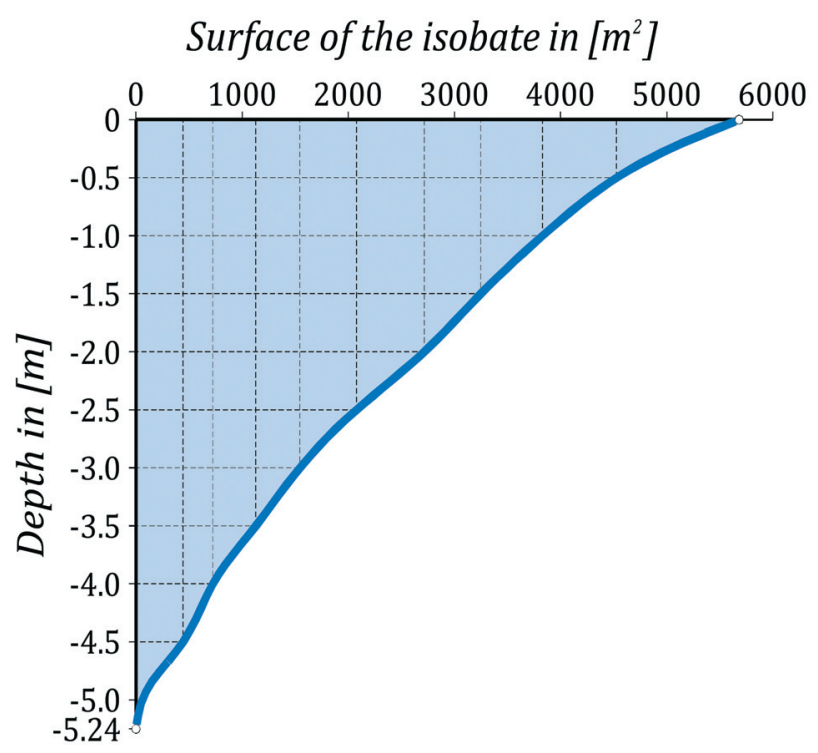

Fig. 10. Graph of the bathygraphical curve of the analysed a part of the Bagry Reservoir, difficult to access.

Rys. 10. Wykres krzywej batygraficznej analizowanej trudnodostępnej części Zalewu Bagry.

the circulation of water in the reservoir and indirectly its ability to biological self-purification.

According to the accepted standards in Poland, the final stage of each finished quarrying should be the technical 
Tab. 1. The basic morphometric parameters of difficult-to-access part of the Bagry Reservoir, according to the ordinate of the water table for 21st March 2016 (zone of ecological site).

Tab. 1. Zestawienie podstawowych parametrów morfometrycznych trudnodostępnej części Zalewu Bagry według rzędnej zwierciadła wody na dzień 21 marzec 2016r (strefa użytku ekologicznego).

\begin{tabular}{|c|c|c|}
\hline Morphometric parameter & $\begin{array}{l}\text { Index of the } \\
\text { parameter }\end{array}$ & Value of the parameter \\
\hline Geodetic coordinates & $\mathrm{X}_{\mathrm{s}}, \mathrm{Y}_{\mathrm{s}}$ & $5544478.02,7427248.15$ \\
\hline Geographic coordinates & $\mathrm{B}, \mathrm{L}$ & $50^{\circ} 01^{\prime} 55.36^{\prime \prime}, 19^{\circ} 59^{\prime} 06.74^{\prime \prime}$ \\
\hline Area of water [m] & $\mathrm{P}_{\mathrm{w}}$ & 5680 (small water body) \\
\hline $\begin{array}{l}\text { The area of the bottom of the water body [m] } \\
\text { (based on the grid } 0.5 \times 0.5 \mathrm{~m} \text { GRID) }\end{array}$ & $\mathrm{P}_{\text {bottom }}$ & 5983 \\
\hline $\begin{array}{l}\text { Ordinate of the water table [m a.s.1.] } \\
\text { according to the state of } 21.03 .2016\end{array}$ & $\mathrm{H}_{\mathrm{zw}}$ & 197.457 \\
\hline $\begin{array}{l}\text { Ordinate of the water table [m a.s.1.] } \\
\text { according to the state of } 14.01 .2018\end{array}$ & $\mathrm{H}_{\mathrm{zw}}$ & 197.560 \\
\hline Length of the shoreline $[\mathrm{m}]$ & $\mathrm{L}_{\text {shoreline }}$ & 364.6 \\
\hline Number of measurement stands of the shoreline & & 130 \\
\hline Maximal length of the water body $[\mathrm{m}]$ & $\mathrm{L}_{\max }$ & 118.7 \\
\hline $\begin{array}{l}\text { Maximal width [m] } \\
\text { (location of the profile, as in the scheme) }\end{array}$ & $\mathrm{S}_{\max }$ & 72.7 \\
\hline Mean width of the water body $[\mathrm{m}]$ & $S_{\text {sr }}$ & 47.8 \\
\hline Maximal depth [m] & $\mathrm{G}_{\max }$ & 5.24 (shallow water) \\
\hline $\begin{array}{l}\text { Mean depth of the water body [m] } \\
\text { (calculated based on } 3387 \text { points) }\end{array}$ & $\mathrm{G}_{\text {sr }}$ & 3.21 \\
\hline $\begin{array}{l}\text { Mean depth of the water body [m] } \\
\text { (calculated based on GRID - } 22527 \text { points) }\end{array}$ & $\mathrm{G}_{\mathrm{sr} \text { GRID }}$ & 2.04 \\
\hline $\begin{array}{l}\text { Mean depth of the water body }[\mathrm{m}] \\
\text { (calculated based on the relationship: } \\
\qquad G_{s r}=\frac{V}{P_{w}}\end{array}$ & $\mathrm{G}_{\mathrm{sr}}$ & 2.03 \\
\hline $\begin{array}{l}\text { Depth indicator } \\
W=G_{\text {Mean }} / G_{\max }\end{array}$ & $\mathrm{W}$ & 0.6 (semi-circular basin) \\
\hline $\begin{array}{l}\text { Coefficient of the shoreline development } \\
\qquad K=\frac{\mathbf{L}_{\text {shoreline }}}{2 \cdot \sqrt{\pi \cdot P_{w}}}\end{array}$ & $\mathrm{~K}$ & 1.4 \\
\hline $\begin{array}{l}\text { Volume of the accessible part of waters }\left[\mathrm{m}^{3}\right] \\
\text { (1) - GRID method } \\
\text { (2) - method of summing up the partial volumes } \\
\text { (3) - method bathygraphic curve }\end{array}$ & $\mathrm{V}$ & $\begin{array}{l}11505^{(1)} \\
11578^{(2)} \\
11560^{(3)}\end{array}$ \\
\hline Scheme & & \\
\hline
\end{tabular}




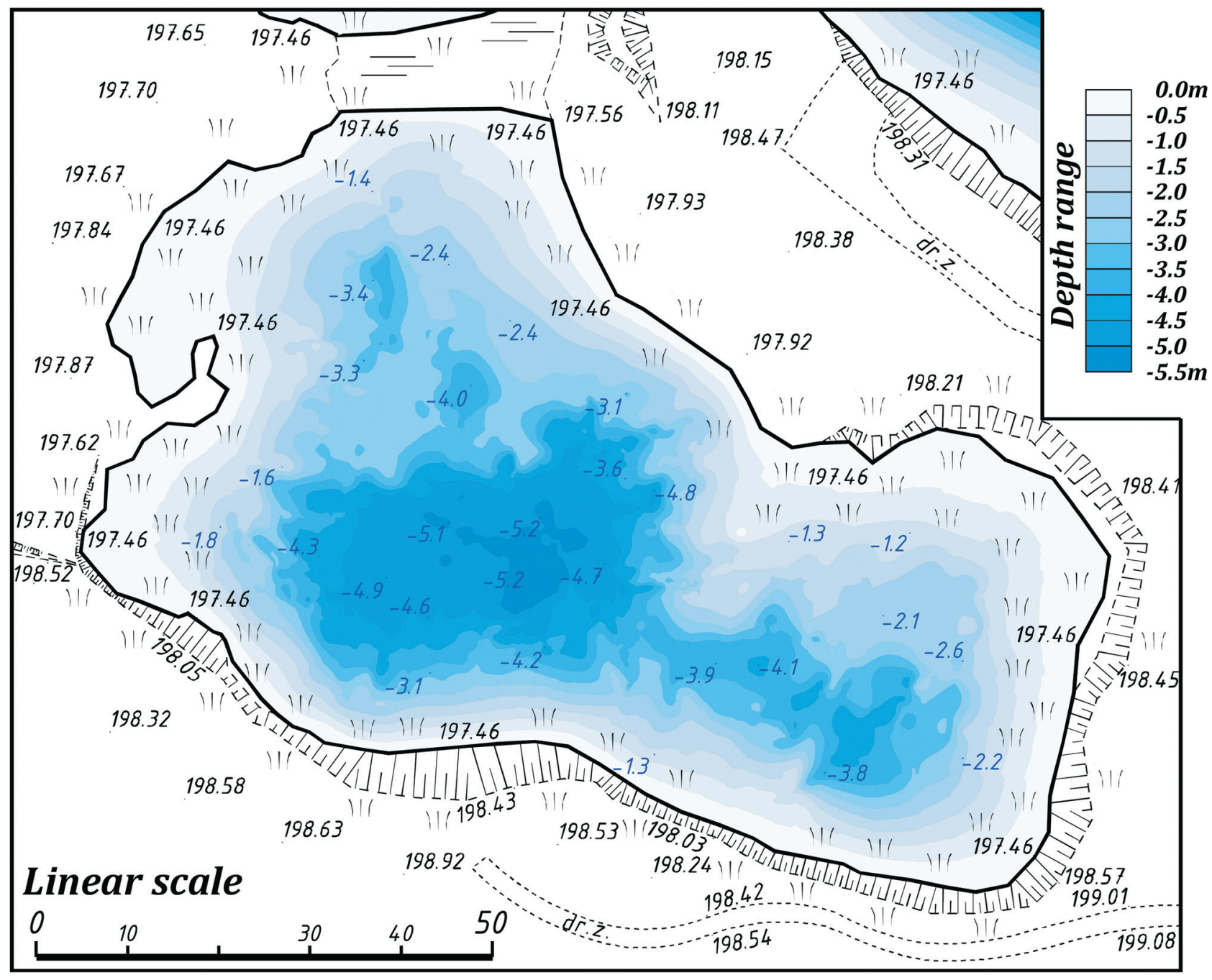

Fig. 11. Bathymetric map of the difficult-to-access part of the Bagry Reservoir (by R. Gawałkiewicz).

Rys. 11. Mapa batymetryczna trudnodostępnej części Zalewu Bagry (opracowanie R. Gawałkiewicz).

(basic) reclamation. Considering technical and economic conditions, in the reclamation of the area of Bagry the following corrections had to be made:

- levelling the surface of the area adjacent to the water part (respective to the relief);

- moderating slope of steep scarps in the submerged part;

- ordering the relief of the bottom of the excavation.

The authors' paper (figures: 5 and 11) show very sophisticated geomorphology of the bottom and the surface of the adjacent area, as well as irregularity of the shoreline. This shows that the end of exploitation in
1972 by the Cracow Enterprise for the Exploitation of Aggregates (Krakowskie Zakłady Eksploatation Kru$s z y w$ - KZEK), did not carry out the any technical (basic) reclamation of this part of the water body. The only contribution to reclamation was given by nature, which covered post-exploitation areas around the water body with meadows and single clusters of bushes and trees.

The qualitative assessment of the bathymetric model, based on the kriging method referred to the following values (Gawałkiewicz R., 2018; Wenrly J.F. et al. 2016):

- mean error (ME), in geostatistics also known as mean residual error, which indicates that the mean difference between the predicted and mea- 
sured value; the value of this error (should be close to zero), is defined by the formula:

$$
M S E=\frac{\sum_{i=1}^{n} R\left(x_{i}\right)}{n}= \pm 0.0002 m
$$

- mean squared error (MSE), providing information to which degree the estimated values are closed to actual values; the value of this error is defined by the formula:

$$
M S E=\frac{\sum_{i=1}^{n}\left[R\left(x_{i}\right)\right]^{2}}{n}= \pm 0.0147 m
$$

- root mean squared error RMSE (root mean squared error), showing the projection accuracy of the topographic area; the value of this error is defined by the formula:

$$
R M S E=\sqrt{\frac{\sum_{i=1}^{n}\left[R\left(x_{i}\right)\right]^{2}}{n}}= \pm 0.0121 \mathrm{~m}
$$

where:

$R\left(x_{i}\right)$ - value of residuum (residual error) in the point of direct hydrographical measurement; this number is a difference between the value of the depth of the interpolated point and the corresponding value of the depth of the measured (control) point;

$n \quad$ - number of variables $n=3518$ (in total: points of depth measurement -3388 and shoreline 130).

Distribution of residua is illustrated in figure 12 .

In total, the area of the terrain of residuum values exceeding the value of $\pm 0.10 \mathrm{~m}$ is $148 \mathrm{~m}^{2}$, which makes $2.6 \%$ of the water body area.

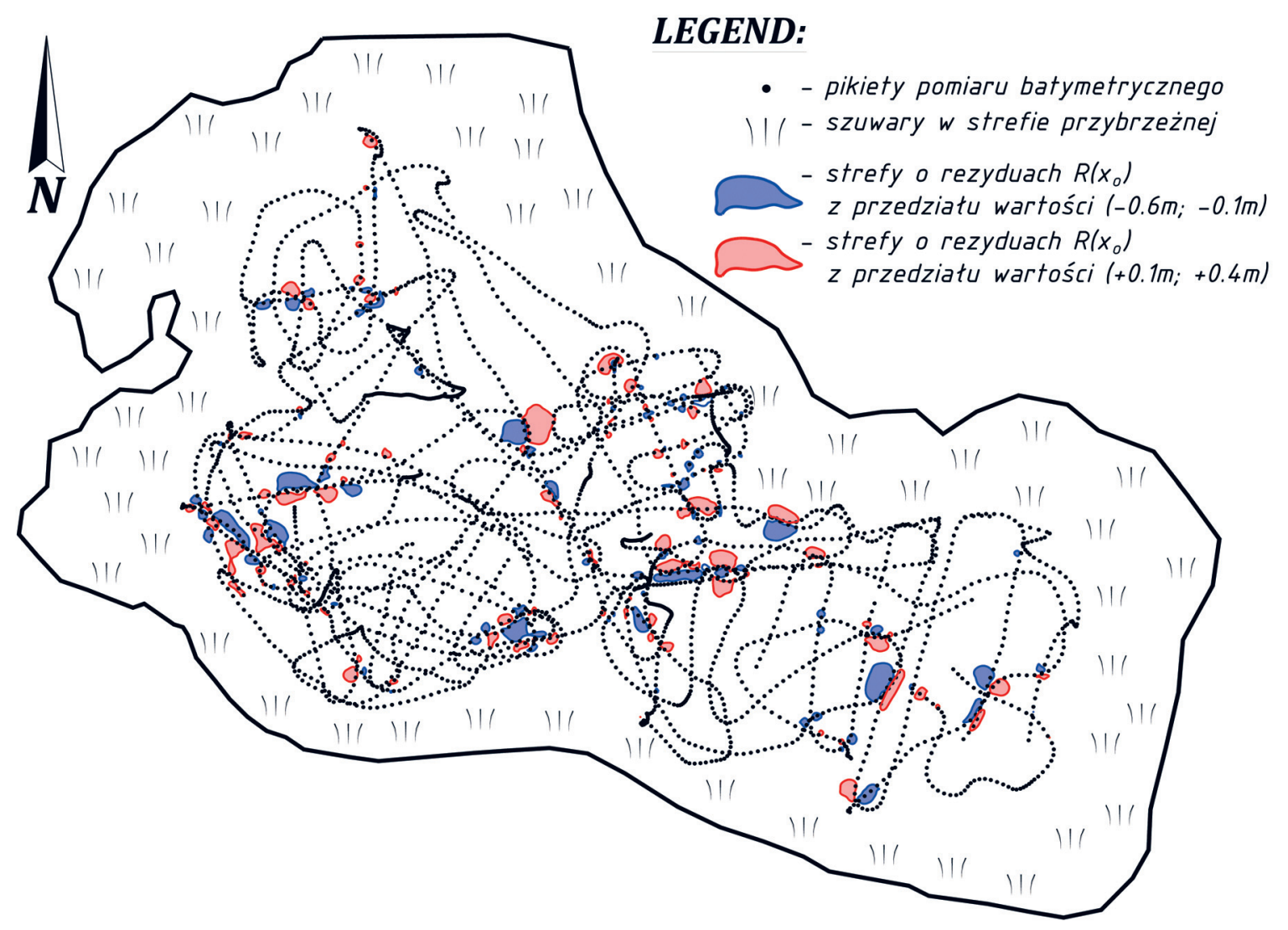

Fig. 12. Graphic distribution of residua of values exceeding $\pm 0.10 \mathrm{~m}$ (picture with the application hachure) on the background of the outline of the analysed part of the water body and hydrographical measurement points.

Rys. 12. Graficzny rozkład rezyduów o wartości przekraczającej $\pm 0.10 \mathrm{~m}$ (metoda obrazkowa z zastosowaniem szrafur) na tle zarysu analizowanej części zbiornika i punktów pomiaru hydrograficznego. 


\section{CONCLUSION}

Planned by the City Council (the owner and administrator of the Bagry Reservoir) revitalization of the water body will be one of many projects enhancing the aesthetic values and attractiveness of this part of Cracow, i.e. Płaszow and Zabłocie. In the neighbourhood of the analysed area alongside the border of the closed railway area, it is planned to plant trees in the of form of hedge, to make a natural noise-proof barrier and improve the aesthetics of the landscape at the Prokocim shore.

The analysed part of the water body today makes very muddy fragment of the water area. Thus the present state of this part of Bagry and the way of its present management makes this area a potentially interesting wildlife enclave situated in the heart of a big city. This means that this small area can in the future become an important point in qualified tourism, oriented to discovering natural values of environment (eco-tourism). Rush vegetation in this part of post-mining area represents high ecological values, making valuable ecosystem of great landscape potential. The protection of such an ecosystem in must be active, including:

- permanent application of measures keeping the flora and fauna in a good shape;

- continuous monitoring (including geodetic monitoring) of water resources and natural environment;

- protecting from direct and indirect devastation, especially from high-depth wells meant to drain the surrounding construction sites belonging to private investors.

For many years geodetic basic maps, scale 1:5 000, have been making base of theme maps for the protection of many habitats of plant and animal species. This it is necessary to update them and improve their accuracy with the use of modern measurement instruments and geoinformatic tools.

Due to the application of modern measurement instruments it was possible to find parameters and make the first in history documentation of this inaccessible part of the water body in the form of the bathymetric map.

\section{REFERENCES}

Bieroński J., (2005): Zbiorniki małej retencji - problemy funkcjonowania, in: „Struktura przestrzenno-funkcjonalna krajobrazu. Problemy ekologii krajobrazu", t. 17, cz. II. Uniwersytet Wrocławski. Wrocław, pp. 101-110.
Budnik A., Dejko M., Kupiec I., Mleczko P., Padoł J., Jedynak M., (2013): Zmiana studium uwarunkowań i kierunków zagospodarowania przestrzennego miasta Krakowa. Prognoza oddziaływania na środowisko. Urząd Miasta Krakowa. Biuro Planowania Przestrzennego - Pracowania Branżowa.

Gawałkiewicz R., (2017): Bagry Lake-volume 2. History written in cartographic archives. Geoinformatica Polonica, no 16. Kraków, pp. 127-138.

Gawałkiewicz R., (2018): The application of integration measurement Technologies In the inventory of the water body of Bagry. Geomatics and Environmental Engineering AGH (in print).

Hełm-Pirgo M., (1928): Kartoznawstwo $i$ wojskowe wyzyskanie terenu. Wydawnictwo Zakładu Narodowego im. Ossolińskich. Lwów-Warszawa-Kraków.

Kudas D., Czempas T., (2016): Modelowanie chwilowej płaszczyzny zwierciadła wody w trakcie pomiarów batymetrycznych. Scientiarum Polonorum Acta Sci. Pol. Formatio Circumiectus 15 (4), pp. 61-72.

Kudłek J., Pępkowska A., Walasz K., Weiner J., (2005): Koncepcja ochrony różnorodności biotycznej miasta Krakowa. INoŚ UJ, Kraków.

Madusiok D., (2016): Analysis of the possibilities for reclamation in the Cracow's quarry of Brzegi by using remaote sensing and geoinformatics. Geoinformatica Polonica, no 15. Kraków, pp. 113-120.

Madusiok D., (2018): Monitoring geodezyjny ruchów mas ziemnych przy eksploatacji kruszywa spod lustra wody waspekcie bezpieczeństwa obiektów inżynierskich. Rozprawa doktorska (niepublikowana). AGH Kraków.

Mytych D., (2017): Przestrzeń rekreacyjna $w$ mieście - rewitalizacja Zalewu Bagry w Krakowie. Przestrzeń i forma, pp. 515-534.

Navico Inc. (2014): Biobase User Reference Guide.

Rozporządzenie Ministra Ochrony Środowiska, Zasobów Naturalnych i Leśnictwa $\mathrm{z}$ dnia 5 listopada 1991r. do ustawy Prawo wodne z 24 października 1974 r., w sprawie klasyfikacji wód oraz warunków, jakim powinny odpowiadać ścieki wprowadzone do wód i do ziemi (Dz.U. 1991, no. 116, poz. 503).

Skórka P., (2007): Zbiorniki poeksploatacyjne - nierozpoznana szansa na wzbogacenie walorów przyrodniczych oraz rozwój rekreacji $i$ turystyki $w$ województwie małopolskim. Nauka i Biznes: Innowacyjne projekty doktorantów UJ. Nauka dla rozwoju Małopolski pod redakcją Pawła Monia i Piotra Żabickiego. Centrum Innowacji, Transferu Technologii i Rozwoju Uniwersytetu (CITTRU). Uniwersytet Jagielloński, Kraków, pp. 48-50.

Szymańska D., (2002): Niektóre zagadnienia urbanizacji w Polsce $w$ drugiej połowie XX wieku. Przemiany Bazy Ekonomicznej i Struktury Przestrzennej Miast. Opole, pp. 53-69.

Wenrly J.F., Zajd H.J., Coon W.F. (2016): Bathymetric Survey and Estimation of Storage Capacity of Lower Sixmile Creek Reservoir. Ithaca, New York, pp. 1-13. 